\title{
Genetic study and molecular breeding for high phosphorus use efficiency in maize
}

\author{
Dongdong LI ${ }^{1}$, Meng WANG ${ }^{1}$, Xianyan KUANG ${ }^{2}$, Wenxin LIU (ه) ${ }^{1}$ \\ 1 Key Laboratory of Crop Heterosis and Utilization (Ministry of Education)/Beijing Key Laboratory of Crop Genetic Improvement/National \\ Maize Improvement Center, China Agricultural University, Beijing 100193, China \\ 2 Department of Biological and Environmental Sciences, Alabama A\&M University, Normal, AL 35762, USA
}

\begin{abstract}
Phosphorus is the second most important macronutrient after nitrogen and it has many vital functions in the life of plants. Most soils have a low available P content, which has become a key limiting factor for increasing crop production. Also, low P use efficiency (PUE) of crops in conjunction with excessive application of $\mathrm{P}$ fertilizers has resulted in serious environmental problems. Thus, dissecting the genetic architecture of crop PUE, mining related quantitative trait loci (QTL) and using molecular breeding methods to improve high PUE germplasm are of great significance and serve as an efficient approach for the development of sustainable agriculture. In this review, molecular and phenotypic characteristics of maize inbred lines with high PUE, related QTL and genes as well as low-P responses are summarized. Based on this, a breeding strategy applying genomic selection as the core, and integrating the existing genetic information and molecular breeding techniques is proposed for breeding high PUE maize inbred lines and hybrids.
\end{abstract}

Keywords maize, phosphorus use efficiency, quantitative trait loci, genetic study, molecular breeding, genomic selection

\section{Introduction}

Phosphorus is a macro element required for biological growth and development, in particular it is essential for the synthesis of important biochemical substances such as DNA, RNA and ATP in all living organisms ${ }^{[1,2]}$. In its natural state in soil, $\mathrm{P}$ exists in the form of organic phosphorus $\left(\mathrm{P}_{\mathrm{o}}\right)$ and inorganic phosphorus $\left(\mathrm{P}_{\mathrm{i}}\right)$, with the former accounting for $50 \%$ to $80 \%$ of soil $\mathrm{P}^{[3,4]}$. As for the

Received May 6, 2019; accepted July 26, 2019

Correspondence: wenxinliu@cau.edu.cn latter, phosphate $\left(\mathrm{PO}_{4}{ }^{3-}\right)$ is the main form. Conversion of $P_{o}$ and $P_{i}$ can be achieved via orthophosphate ${ }^{[5-7]}$. $P_{i}$ has three states in the soil: water-soluble, adsorbed and mineralized. However, most of the phosphates are chelated or precipitated with $\mathrm{Fe}^{2+}, \mathrm{Al}^{3+}$ and $\mathrm{Ca}^{2+}$ ions, which results in the fixation of phosphate ions in the soil. Only a very small number of the water-soluble ions $\mathrm{H}_{2} \mathrm{PO}_{4}{ }^{-}$and $\mathrm{HPO}_{4}{ }^{2-}$ can be directly used by plants, accounting for less than $0.01 \%$ of available $P$ in the soil and even less than $0.001 \%$ in the low-P fields. As a result, $\mathrm{P}$ use efficiency (PUE) in the soil ranges from $20 \%$ to $30 \%$, limiting crop yields by $30 \%-40 \%^{[1,7-12]}$. Meanwhile, temperature, moisture, $\mathrm{pH}$ and other soil factors also affect the $\mathrm{P}$ concentration and form. The dynamic balance of $\mathrm{P}$ in the soil is important for regulating the circulation of nutrients in nature ${ }^{[3,5]}$. Moreover, the worldwide status of $\mathrm{P}$ resource utilization has been of great concern in that 5.7 billion hectares of soil is deficient in P. Meanwhile, the demand for $P$ fertilizers will reach its peak in $2033^{[13,14]}$. In addition, the excessive application of $\mathrm{P}$ fertilizers has caused serious environmental pollution problems. Hence, it is extremely urgent to improve the PUE of crops.

Facing the increasing contradiction between the global population growth and the shortage of $\mathrm{P}$ resources, it is paramount to understand the molecular mechanisms of crop P utilization in order to further improve crop PUE. By using genetics and molecular biology methods to select P-efficient crops, significant economic and ecological benefits can be derived. In this review, the characteristics of P-efficient inbred lines are summarized by comparing the phenotypic and omics changes of different genotypes under low-P stress. Furthermore, PUE-related quantitative trait loci (QTL) or genes in maize, which have previously been mined, are assessed for their suitability to conduct molecular breeding. Differences in the tolerance to low-P conditions between different heterotic groups and the changes of heterotic patterns under low-P stress are reanalysed and summarized. Finally, we propose an integrated molecular breeding strategy taking genomic 
selection (GS) as core to select P-efficient inbred lines and hybrids, which will provide a theoretical basis for breeders to select high PUE materials.

\section{Phosphorus use efficiency in plants}

Plants absorb P mainly through roots, which is a complex process affected by the chemical and physical state of soil, the interaction between roots and soil, and the interaction between roots and microorganisms ${ }^{[15]}$. PUE, as used here, is the ratio of grain yield or biomass per unit $\mathrm{P}$ supply in a low-P environment ${ }^{[16-19]}$. PUE can be split into two parts, $\mathrm{P}$ uptake efficiency (PupE) and $\mathrm{P}$ utilization efficiency (PutE). The relationship among these is $\mathrm{PUE}=\operatorname{PupE} \times$ PutE ${ }^{[18,20,21]}$. PupE can be calculated using the formula, $\operatorname{PupE}=\mathrm{P}_{t} / \mathrm{P}_{\text {soil }}$, where $\mathrm{P}_{\mathrm{t}}$ is the total $\mathrm{P}$ content including grain and shoot tissues and $\mathrm{P}_{\text {soil }}$ is the total amount of $\mathrm{P}$ available in soil. PutE can be calculated using the formula PutE = grain yield $/ \mathrm{P}_{\mathrm{t}}^{[18,22]}$. PupE refers to the ability of plants to absorb $\mathrm{P}$ from the soil, which is affected by the root morphological architecture, soil state and microorganism $^{[23,24]}$. Furthermore, PutE is related to the ability of plants to transfer absorbed $\mathrm{P}$ into yield ${ }^{[25]}$. In plants, the $\mathrm{P}_{\mathrm{i}}$ transporters, for instance, promote the transport of $\mathrm{P}$ between roots and soil surface as well as between different tissues and organs ${ }^{[9,24]}$. Under low-P stress, in a maize recombinant inbred lines (RIL) population, the correlation between PupE and PUE is different from that between PutE and PUE. The former ranges from 0.48 to 0.53 , and the latter from 0.32 to $0.38^{[26]}$. Also, the respective contribution of PupE and PutE to PUE is different, with PupE explaining $71 \%$ to $100 \%$ of maize hybrid yield variation $^{[27,28]}$. Therefore, PupE is the focus of genetic improvement.

\section{Genotypic differences in response to low-P starvation in maize}

Under low-P stress, P-efficient lines show dominance in biomass in that they have greater root: shoot ratio, nodal rooting, nodal root laterals, adventitious roots, root hair density and basal root whorl number but less root cortex than P-inefficient lines ${ }^{[25,29-31]}$. The regulation of hormones, such as auxin, ethylene, gibberellic acid and abscisic acid, changes the root morphology of plants, namely, the number of primary roots, the length of lateral root and root hair, and increases the secretion of organic acid ions, protons, neutrons and phosphatases, which increase the crop P uptake ${ }^{[19,24,30,32-34]}$. Physiological responses to $\mathrm{P}$ deficiency involve the release of organic acids, protons and enzymes and modifications of root architecture $^{[10,26]}$. Analyzing the physiological indicators of Qi319 and its mutant Qi319-96, showed P-efficient line Qi319-96 had a better ability to reconstruct lipid composi- tion of membranes and had higher V-ATPase activity under $\mathrm{P}$ deficiency condition ${ }^{[35]}$. Taking the P-efficient maize inbred line W23 and the P-inefficient inbred line W22 as research objects, under a hydroponic low-P environment, $\mathrm{H}^{+}$and $\mathrm{Ca}^{2+}$ ions in $\mathrm{W} 23$ were increased by $89 \%$ and $225 \%$, respectively, the shoot biomass of W23 was $38 \%$ higher than W22, but there was no difference in root biomass between the two lines. Nevertheless, the W23 root elongation zone was significantly longer than that of $\mathrm{W} 22^{[36]}$. Under the low-P stress, carboxylate efflux from roots can also be used as an important reference factor for screening P-efficient lines ${ }^{[37]}$. Under low-P stress, plant leaves accumulate more anthocyanin pigments to protect chloroplasts and nucleic acids in tissues; additionally, plant height and ear height are reduced, but the plant height: ear height ratio is increased ${ }^{[38,39]}$. Under two different low-P conditions, for an inbred population, the number of kernels per ear decreased respectively by $24 \%$ and $28 \%$, and the yield decreased by $36 \%$ and $31 \%$, respectively ${ }^{[40]}$. When the phenotypes of different traits of a maize population were assessed, it was found that the low-P tolerance in different genotypes was significantly correlated with the phenotype of plants under low P. Both can be used for screening and genetic analysis of low-P tolerant germplasm $^{[41]}$. According to the definition of PUE, biomass and yield are still the main selection criteria when screening for P-efficient germplasm, but both traits are very complex quantitative traits controlled by many minor QTL ${ }^{[42-44]}$.

\section{Plant molecular responses to low-P starvation in maize}

Plants have developed a complete system to adjust $\mathrm{P}$ absorption, utilization and recycling in order to ensure normal growth and development under low-P stress. This process is known as the phosphate starvation response (PSR) ${ }^{[19,45]}$ and involves changes to transcriptional, genomic, and metabolic regulatory networks. By analyzing the maize root transcriptome of P-efficient lines on different days after $\mathrm{P}$ deficiency, 820 upregulated and 363 downregulated response genes involved in metabolic, signal transduction, and developmental gene networks were identified ${ }^{[46]}$. In maize, five $P h t 1$ genes which contribute to phosphate uptake and allocation across soil and shoot have been identified ${ }^{[47]}$. Through comparison of sequencing RNA reads of Qi319 and 99038 under normal and low-P environments, the researchers identified seven novel and known miRNA families ${ }^{[48]}$. Additionally, a study by Du et al. ${ }^{[49]}$ showed that the miRNA399-ZmPHO2 pathway is key in the regulation of $\mathrm{P}$ uptake, and LncRNA1 interacts with miRNA399 to make plants adapted to low P. By comparing and the root proteome of Qi379 and its mutant 99038, 73 upregulated and 95 downregulated differentially expressed proteins were identified. These proteins were involved in cellular and metabolic processes, 
especially in carbon metabolism and cell proliferation ${ }^{[50]}$. By analyzing the phosphoproteome and proteome of Qi319 roots in four stages, it was revealed that 6\% phosphoprotein involved in metabolic and cellular pathways changed under low-P treatment, and low P induced the modifications of carbon flux in metabolic processes ${ }^{[51]}$. P-sensitive line HM-4 and P-tolerant line PEHM-2 were used to investigate the $\mathrm{P}$ starvation effect at the metabolite level. Analysis of the results showed that accumulation of di- and trisaccharides and metabolites of ammonium metabolism, particularly in leaves, and decrease of phosphate-containing metabolites and organic acids as well as increase of glutamine, asparagine, serine in shoot and root occurred ${ }^{[52]}$.

\section{Genetic study of PUE-related traits}

The PSR of plants leads to changes in plant phenotype, which are the basis for selecting high PUE genotypes. However, genetic analyses are the foundation for understanding the metabolic pathways and molecular breeding. The genetic structure of the target trait includes the number of QTL controlling the traits, the QTL effect, the mode of action of QTL (additive, dominant and epistatic effects) and the genotype-by-environment interactions ${ }^{[53]}$. Based on the research purpose, the traits related to $\mathrm{P}$ efficiency are divided into four categories: (1) traits related to $\mathrm{P}_{\mathrm{i}}$ availability in the soil; (2) traits related to $\mathrm{P}$ uptake by plant roots; (3) traits related to $\mathrm{P}$ utilization; and (4) yieldrelated traits ${ }^{[25]}$. In maize research, information on many effective QTL has been mined using different genetic populations (Table 1).

The genetic architecture of PUE, PutE and PupE traits of a population of 140 RILs backcrossed with both parental lines, P-efficient inbred line L3 and the P-sensitive inbred line L22, showed that the dominant effects contributed more to PUE and its components than the additive effects. Importantly, the QTL detected for PUE correspond to 80\% of those found for PupE traits, indicating that PupE and PUE have a similar genetic basis ${ }^{[22]}$. Using a $\mathrm{BC}_{1} \mathrm{~F}_{5}$ established by crossing rice varieties Nipponbare and Kasalath, traits such as P uptake, PUE, dry weight and tiller number were identified in a low-P environment. QTL were found on chromosomes 2, 4, 6, 10 and 12, and of those QTL, a QTL at the interval of G227-C365 on chromosome 2 was found for both P uptake and PUE. Likewise, a QTL at the marker interval G2110-C443 on chromosome 12 was found consistently for the traits of P uptake, PUE, dry weight, and tiller number. Subsequently, by constructing a chromosome segment substitution line population, the important QTL Phosphorus uptake 1 (Pup1) was identified $^{[69,70]}$. Phosphatase activity is also very important for plant roots to absorb P. Qiu et al ${ }^{[68]}$. used the inbred lines, 082 and $\mathrm{Ye} 107$, as parents to construct a $\mathrm{F}_{2: 3}$ population of 180 individuals. A stable QTL in the bnlg1350-bnlg1449 region of chromosome 10 was found for the acid phosphatase activity in roots. Two stable QTL, one at umc2083-umc1972 on chromosome 1 and the other at umc2111-dupssr10 on chromosome 5, were found for acid phosphatase activity in rhizosphere soil. Subsequently, phosphatase activity in leaf tissue in two low-P environments was assessed for QTL mapping, and six QTL were identified. Only QTL $A P 9$, located within the $546 \mathrm{~kb}$ interval of chromosome 9 ac219-ac2096 marker interval, was found in different environments ${ }^{[67]}$. Cai et al. ${ }^{[39]}$ used plant and ear height combined with yield-related traits in a low-P environment for QTL mapping, which resulted in a total of 25 QTL. QTL mapping was performed for leaf area, leaf chlorophyll content, flowering and yield traits under low-P in bin 2.03/2.04, bin 2.06/2.08, bin 4.01/4.02, bin 5.03/5.04, bin 6.07, bin 9.03, bin 10.03/10.04 intervals, when mining QTL for the different traits ${ }^{[65]}$. By taking the root traits of the RIL population (including the lateral root length, the lateral root number and the plasticity of lateral root number) under low-P as target traits, five QTL were mined on chromosomes 1, 2, 3 and 6 for lateral root length, with the largest phenotypic variance explained (PVE) of $9.98 \%$ and the smallest PVE of $4.04 \%$. A QTL with a PVE of $10.4 \%$ was found on chromosome 2 for lateral root number, and a QTL with a PVE of $10.2 \%$ was found on chromosome 4 with regard to the plasticity of lateral root number ${ }^{[56]}$.

In addition to QTL mapping using a biparental population, genome-wide association analysis (GWAS) based on linkage disequilibrium using the historical recombination of inbred lines results in a higher resolution of mapping and has achieved great success in resolving complex traits of plants ${ }^{[71-74]}$. However, there are only a few reports on using GWAS to analyze PUE or low-P tolerance-related traits. $\mathrm{Xu}$ et al ${ }^{[40]}$. used two association populations to perform GWAS analysis using phenotypes under low-P stress and low-P tolerance index (LPTI). The target traits comprised biomass, development-related traits and yield-related traits. Using the differentially expressed genes in the transcriptome data of the P-tolerant line CCM454 and the P-sensitive line 31778 as a validation, a total of 259 significantly associated genes were mined, which were mainly involved in four biochemical pathways, viz., transcriptional regulation, reactive oxygen scavenging, hormone regulation and remodeling of cell wall. Luo et $\mathrm{al}^{[75]}$. used 338 inbred lines to perform GWAS analysis and found five significant peaks for morphological traits. Metabolites with significant differences in the extreme pools of six P-sensitive inbred lines and six Ptolerant inbred lines were detected. Furthermore, by combining significantly associated SNPs with genes involved in different metabolite pathways, five genes, GRMZM2G050570, GRMZM2G039588, GRMZM2G051806, GRMZM2G039588, GRMZM5G841893 were identified. These two studies combined GWAS with transcriptome or metabolome data to mine genes involved in the $\mathrm{P}$ 


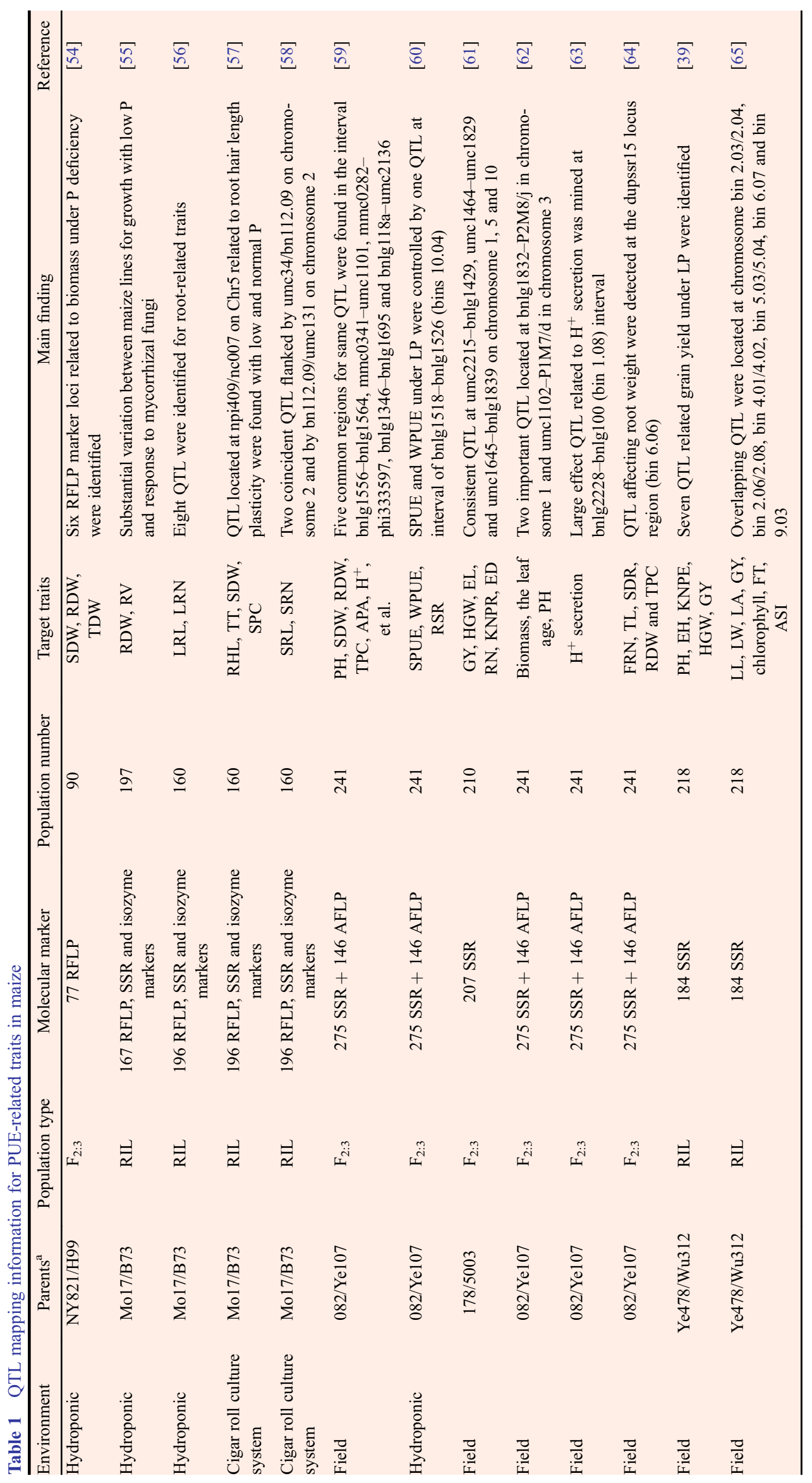




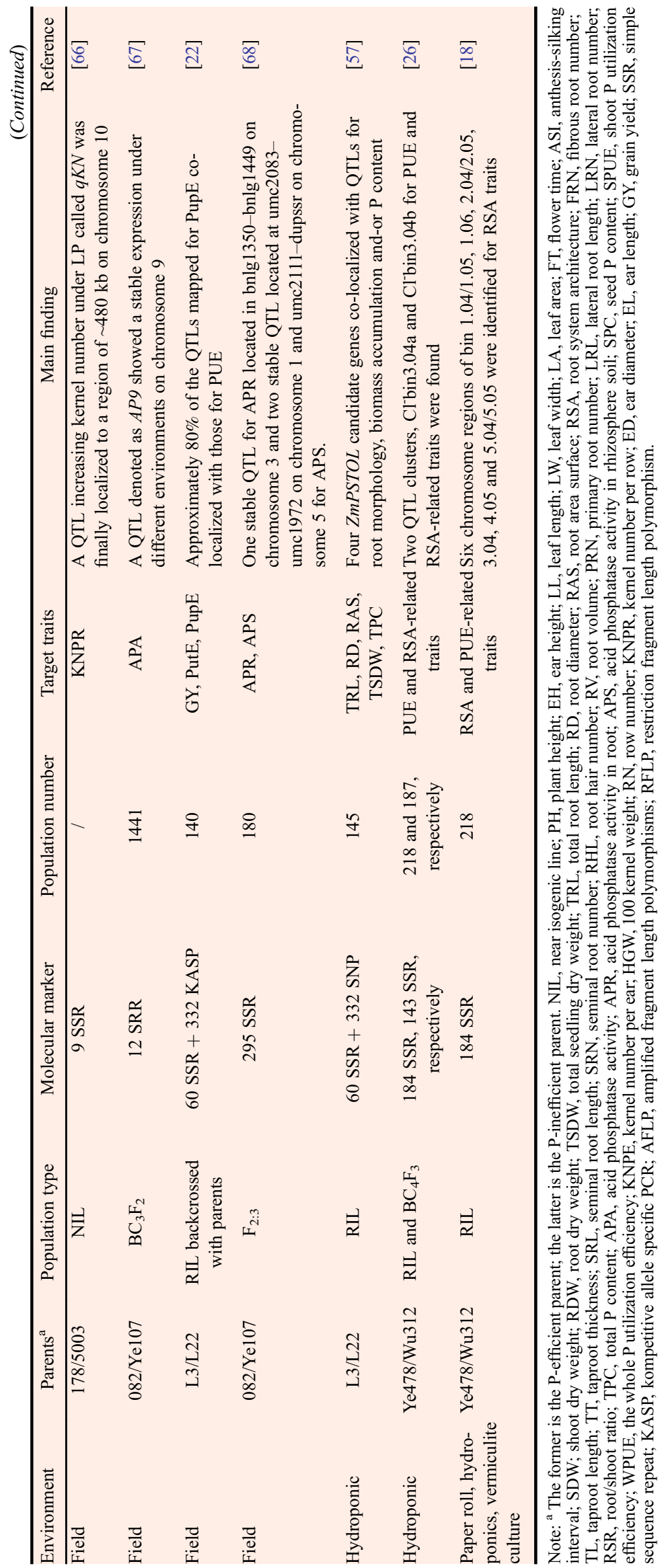


metabolic pathway. The approach of combining multiomics data results in a better understanding of the inheritance and regulatory pathways of PUE-related traits.

Some synthetic multiparent populations such as nested association mapping, multiparent advanced generation intercrosses, multiparent population consisting of serval doubled haploid (DH) or RIL populations combine the advantages of linkage analysis and association mapping. At the same time, rich genomic and phenotypic variation and a clear genetic structure of maize make it possible to resolve many complex traits with greater flexibility and efficacy ${ }^{[76-82]}$. Although such multiparent populations have unparalleled advantages in QTL mapping and genetic analyses, genetic studies of low-P tolerance are currently limited to biparental QTL mapping and association mapping. Hence, there is still considerable scope for improvement of genetic population studies for PUE.

\section{Phenotypic difference between heterotic subgroups}

Heterosis refers to the phenomenon where the phenotype of the $F_{1}$-generation performs better than those of parents, and maize is the most successful crop for the utilization of heterosis. A study using 456 inbred lines and their phenotypic data of shoot and root at the seedling stage in a normal and low-P environment led to the classification of lines into low, medium and high tolerance to low-P conditions, and specifically, the identification of 23 P-efficient and $109 \mathrm{P}$-sensitive lines. P-efficient lines in the temperate subpopulations were $1323,81162,04 \mathrm{~K} 5672$ and Dan599, P-efficient lines in the tropical/subtropical subpopulations were CIMBL120, CIMBL131, CIMBL14 and CML431, P-inefficient lines in the temperate subpopulations were Dan340, Zheng22, ZZ01, XZ698, and P-inefficient lines in the tropical/subtropical subpopulations were CIMBL10, CIMBL106, CIMBL110 and CIMBL114 ${ }^{[83]}$. Based on the agronomic traits and yield traits of 826 lines (including 580 tropical/subtropical and 246 temperate maize inbred lines), the synthetic LPTI was calculated to screen for high PUE lines. The temperate low-P-tolerant inbred lines in the temperate subpopulations were CXS100, Fu746 and LH51, the low-P-inefficient inbred lines in the tropical/subtropical subpopulations were CML426, CML432 and CML470, the P-inefficient lines in the temperate subpopulation were CXS132, CXS135, CXS18 and CXS21, and the low-P-inefficient lines in the tropical/subtropical subpopulations were CML486, CML454, CML40 and CML29860 ${ }^{[41]}$. By rearranging the data of Zhang et al. ${ }^{[1]}$, it can be found that the temperate lines have higher tolerance to low $\mathrm{P}(P<0.001)$ (Fig. 1).

$\mathrm{Xu}$ et al. ${ }^{[40]}$ used the same index as Zhang et al. ${ }^{[41]}$ to perform genetic analysis of low-P-tolerant lines to screen germplasm resources. P-efficient inbred lines were CP619F, JI35, 89-1 and 374, whereas P-inefficient lines were 200B, LH193, LH220HT and 4676. It is clear that the genetic materials selected in different studies differed greatly, which was mainly due to (1) differences in genetic materials per se; and (2) the differing target traits and indicators. Therefore, the question of which indicator should be used to screen for low-P-resistant lines is still open to discussion. Most studies use phenotypes under

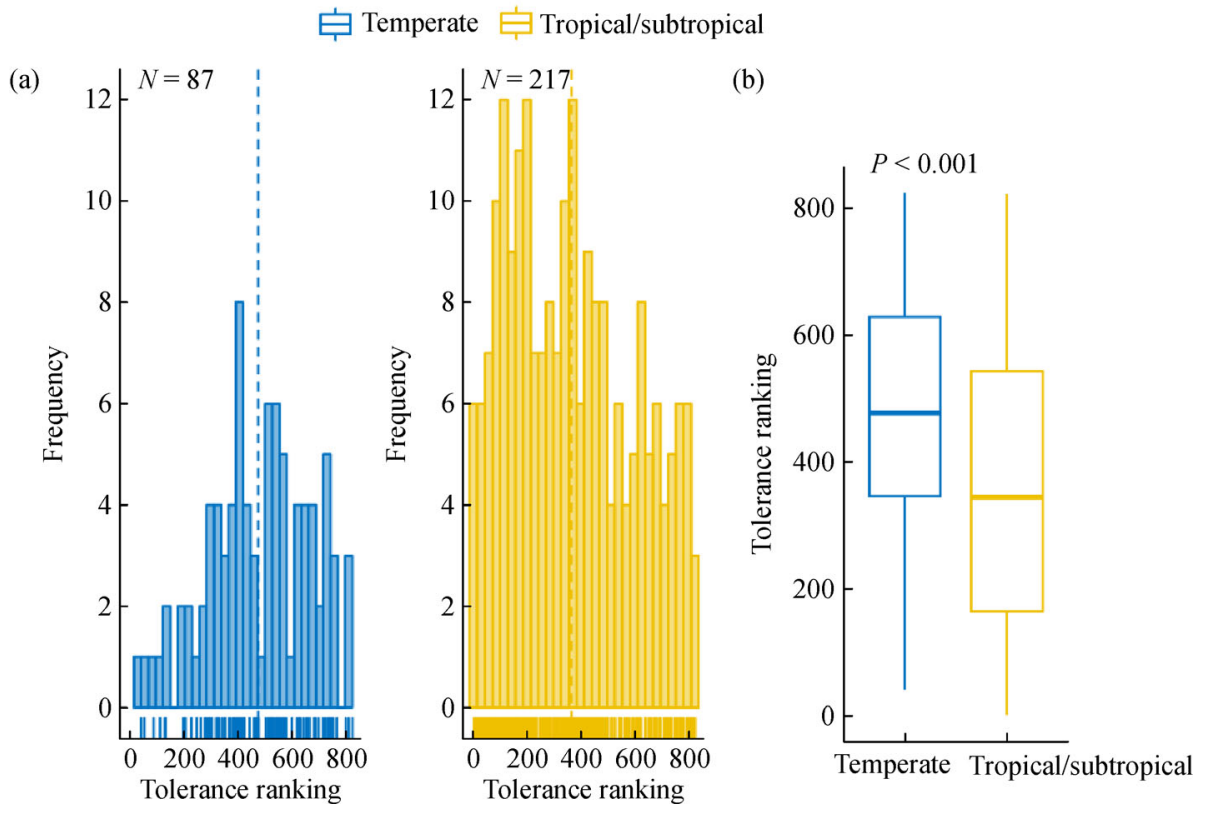

Fig. 1 Distribution of low-P tolerance ranking of temperate and tropical/subtropical subpopulations. (a) Histogram of tolerance ranking of temperate (left) and tropical/subtropical (right); (b) boxplot of tolerance ranking of the two subpopulations. Significance test was based on Student's $t$-test. Data sources from Zhang et al. ${ }^{[41]}$. 
low-P stress or LPTI as screening indicators.

Liu et al. ${ }^{[84]}$ used three P-efficient inbred lines (Zao27, 428 and YuanYin1) and three P-inefficient inbred lines (7922, Chen9411 and 8703-2) as parents to produce $15 \mathrm{~F}_{1}$ hybrids by crossing as a complete diallel. It was found that for most traits, under the stress of low $\mathrm{P}$, the relative midparent heterosis changed from $20.3 \%$ to $446 \%$, while it varied between $-7.73 \%$ and $2308 \%$ under high-P conditions, and that the midparent heterosis of most root system architecture-related traits under low $\mathrm{P}$ was higher than that under normal P. Ige et al. ${ }^{[85]}$ used 10 open pollinated cultivars to construct hybrids by a complete diallel cross. Their work revealed that the midparent heterosis and the better-parent-heterosis are reduced under low-N stress. Moreover, AMATZBR-WC2B (white flint) with flint endosperm and white grain color showed the highest general combining ability (GCA). DMR-LSR-Y (yellow dent) with dent endosperm type and with yellow grain color and BR9943DMRSRG (white flint) with flint endosperm and white grain color had the lowest GCA. Under low-N conditions, the hybrids DMR-LSR-W (yellow dent) $x$ BR9928DMRSR (yellow flint) and BR9922DMRSR (yellow flint) $x$ TZBRELD-4C0W (white flint) have the highest specific combining ability (SCA). Narang \& Altmann ${ }^{[86]}$ used two Arabidopsis accessions, C24 and Col-0, which differed in the absorption capacity of hydroxyl phosphate, and found that the heterosis of $F_{1}$ hybrids was derived from the accumulation of a large number of excellent dominant genes. The hybrids inherited the long root hair length of $\mathrm{C} 24$, the long root length of Col-0, and the enhanced phosphate transporter expression of C24. Physiological genetic changes result in hybrids with a higher PUE. Under low-P stress, phenotypic analysis of lines and hybrids from different heterotic groups is used to identify high GCA inbred lines and high SCA hybrids, which in turn are promising candidates for evaluating, predicting, and selecting high PUE maize hybrids.

\section{Molecular breeding methods in plants}

Standard breeding mainly chooses individuals according to their phenotypes, which has great utility. Molecular markers can be used to select the background and foreground of genetic material, and to achieve gene pyramiding, which improves the accuracy and predictability of maize breeding ${ }^{[87]}$. In Arabidopsis, MYB62, $A R F 7$ and ARF19 have been reported to increase the absorption of $\mathrm{P}$ by $\operatorname{root}^{[88,89]}$. Pupl is a very important QTL located on chromosome 12 of rice, with the rice variety Kasalath serving as the donor of this favorable allele. It was found that in low-P soils, the P uptake and yield of lines carrying Pup 1 were higher, which holds true for different genetic backgrounds and environments ${ }^{[90]}$. Furthermore, overexpressing the PSTOL1 gene, which encodes a protein kinase, confers a phenotype of increased root dry weight, $\mathrm{P}$ uptake, and yield in the rice varieties IR64 and Nipponbare ${ }^{[13]}$. By homologous alignment with published PUE-related genes in rice and Arabidopsis, many genes with potential applications in maize had been discovered, for example GRMZM2G017164 ${ }^{[13]}$, GRMZM2G111354 ${ }^{[32]}$, GRMZM2G135978 ${ }^{[91,92]}$. However, there has been no report of the application of genes in maize breeding until now. In recent years, a series of gene editing technologies have become increasingly common in human and plant research, among which the most widely and successfully used technology is CRISPR $^{[93]}$. The CRISPR system has been used to improve quality and quantity traits of maize ${ }^{[94,95]}$. CRISPR technology only transforms endogenous genes and has broad prospects for application in the creation of new genetic breeding lines. For maize, there is no report on the use of CRISPR technology to obtain high PUE maize germplasm. This underlines the fact that knowledge of a gene or QTL is necessary for its application via MAS, transgenic approaches, or CRISPR.

In 2001, Meuwissen et al ${ }^{[96]}$. proposed the concept of GS, in which molecular markers covering a whole genome and phenotypic information of a training population are used to establish linear models (such as rrBLUP, BayesA and GBLUP) to predict the genomic estimated breeding value $^{[97]}$. Bernardo and $\mathrm{Yu}^{[98]}$ performed a simulation analysis in maize $\mathrm{DH}$ breeding and demonstrated that genome-wide selection has greater genetic advances than MAS. Subsequently, GS has been widely carried out in the study of maize inbred line selection, hybrid phenotypic and heterosis prediction, and has achieved great efficiencies in important agronomic traits, quality and yield of maize ${ }^{[99-}$ 106]. The prediction accuracy of GS is affected by multiple factors, such as the genetic structure of a trait, the number of markers, the size of the training population, and the kinship among individuals ${ }^{[107-110]}$. Lyra et al. ${ }^{[111]}$ used phenotypes under low-N to calculate different selection indices and used GBLUP and RKHS/GK to evaluate the accuracy of single-trait and multi-trait models. For the two investigated models, the highest accuracy of harmonic mean index was 0.4 and 0.41 , respectively. The multi-trait model can also improve the GS accuracy of yield. By using an association population of 11 phenotypes, it was observed that haplotype-GS comprising the information of linkage disequilibrium and wBayes with the information of significant QTL have a higher prediction accuracy for some simple traits ${ }^{[40]}$. Therefore, the method of GS has a high accuracy and genetic progress for prediction and screening of high PUE lines is enhanced.

\section{Molecular breeding for high PUE in maize}

Based the research discussed above, we propose a strategy for screening P-efficient maize lines and cultivars by 


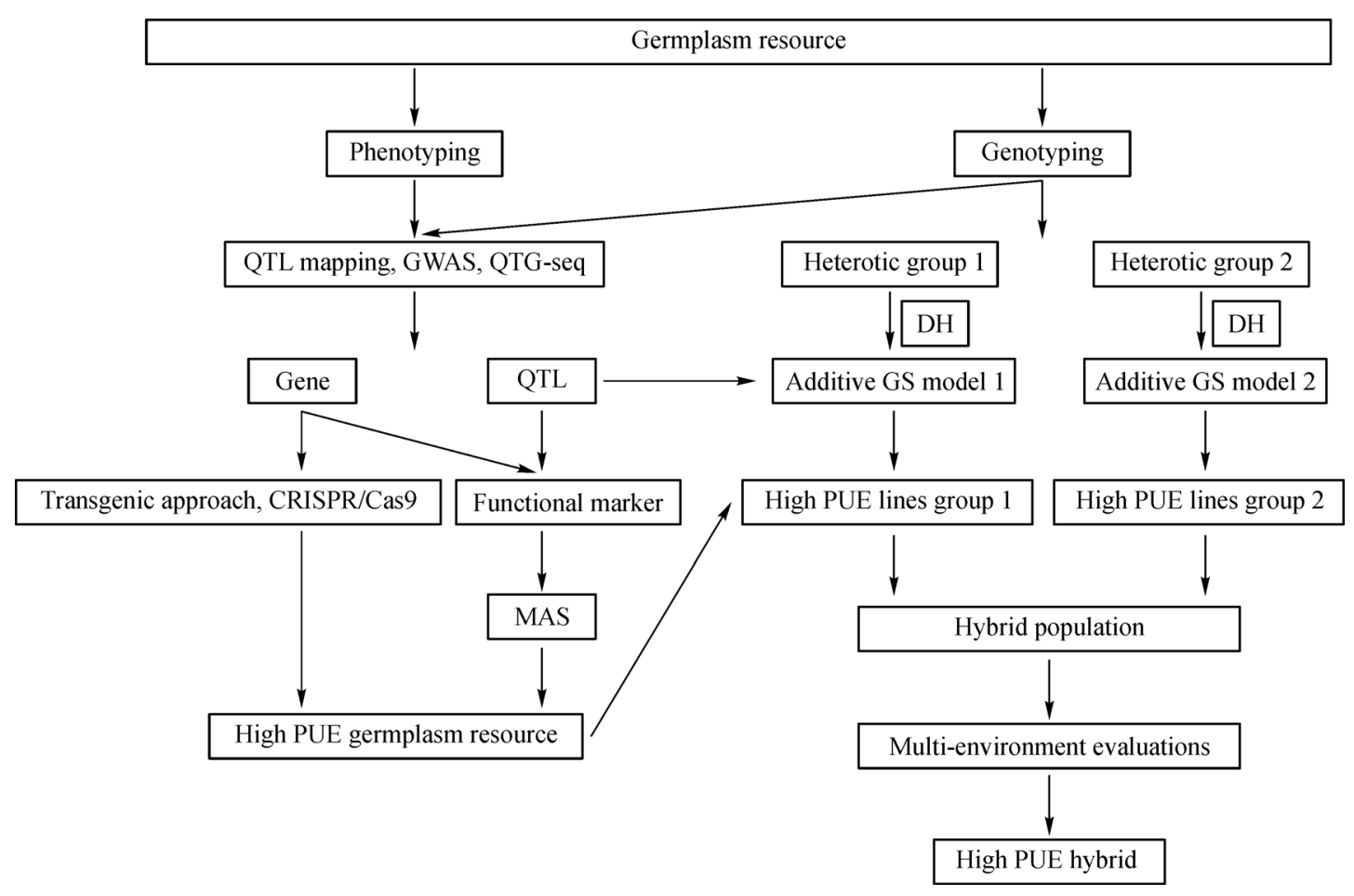

Fig. 2 A strategy for breeding high PUE inbred lines and hybrids.

combining various molecular breeding methods (Fig. 2).

Rich genetic resources are the basis for crop genetic improvement and breeding ${ }^{[112-114]}$. Organizations such as the Chinese Academy of Agricultural Sciences, the International Maize and Wheat Improvement Center and Leibniz Institute of Plant Genetics and Crop Plant Research have established gene banks, and researchers can order seed resources online. Since the sequencing of maize variety B73 in $2009^{[115]}$, large-scale whole-genome sequencing of maize has been undertaken, and 1.25 million markers of 540 inbred lines have been constructed by integrating RNA-Seq data, $50 \mathrm{~K}$ chips and genotyping by sequencing data ${ }^{[116]}$. By means of the whole genome sequencing data of 1218 inbred lines, researchers constructed the third generation HapMap of maize ${ }^{[117]}$ and the genome sequencing data has been shared on the web page of 'maizego' and 'panzea'. At present, in most studies, the collection of phenotypic data still relies on labor, but largescale high-throughput automated phenotypic identification platforms have been established to overcome this limitation $^{[118]}$. For example, candidate gene mining by combining high-throughput agronomic phenotypic data and correlation analysis has been performed in rice ${ }^{[119]}$. Imaging systems have also been applied to study plant $\operatorname{roots}^{[75]}$, and this automated phenotypic identification platform is likely to have broad application in crop phenotypes and genetic research. Also, statistical methods for the association of phenotypic and genotypic data are used for linkage mapping and GWAS. Other methods that only use extreme plant materials for gene mapping (such as

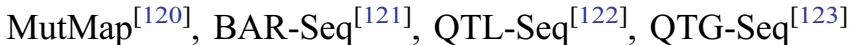
and XP-GWAS ${ }^{[124]}$ ) have proved beneficial in genetic research on quality and quantitative traits. Moreover, bulked segregant analysis of genomes, metabolomes, and proteomes has great potential for genetic mapping, plant breeding, and molecular marker development ${ }^{[125]}$. Overall, with the above resources and technologies that allow increased knowledge for a candidate gene or QTL we then can use MAS, transgenic approaches and CRISPR to verify the candidate gene function(s) and select targeted chromosome fragments for genetic improvement, thereby achieving superior gene selection and broadening the genetic basis for low-P tolerance in maize.

Since maize is a crop with strong heterosis, it is not enough to only select or improve elite inbred lines; rather, it is necessary to select excellent inbred lines in different heterotic groups to form hybrids. Within each heterotic group, DH technology can be used to obtain pure inbred lines in early generations. Based on the genotypic information of these lines, the subgroup structure of the lines can be determined by using the methods of principal component analysis and genetic distance ${ }^{[72,126-128]}$. There are two main advantages to grouping genetic materials: (1) the farther the genetic distance between subgroups, the greater the heterosis ${ }^{[129,130]}$; (2) the kinship of the lines within one subgroup is close, and the relationship between the training group and the testing group is close, which can lead to a high accuracy of $\mathrm{GS}^{[101,109,131-133]}$. According to a clustering structure, a GS model can be established in each subgroup. The difficulty in phenotyping a large 
number of DHs can be solved by using GS methods to predict the PUE-related traits. At the same time, QTL or genetic information related to PUE traits can also be integrated into a GS model to improve prediction accuracy ${ }^{[134]}$. Hybrid breeding entails selecting elite inbred lines with a high GCA, followed by crosses of pairs of lines with a high SCA. Therefore, some core germplasm resources should be selected from each subgroup to make test crosses. Then, a hybrid prediction model can be established based on the multienvironment evaluation for hybrids and their parental lines ${ }^{[135,136]}$. In addition, the genotype by environment interaction can be integrated into a linear model to improve accuracy ${ }^{[137-139]}$, thereby achieving the selection of high PUE hybrids.

Acknowledgements We thank Thea Mi Weiß and Dr. Kesheng Wang for their substantial contribution to the revision of this review. This project was supported by the National Key Research and Development Program of China (2018YFD0100201 and 2016YFD0101201), the Scientific Research Foundation for the Returned Overseas Chinese Scholars, Ministry of Education of China, and the Sino-German International Research Training Group "Adaptation of maize-based food-feed-energy systems to limited phosphate resources."

Compliance with ethics guidelines Dongdong Li, Meng Wang, Xianyan Kuang, and Wenxin Liu declare that they have no conflicts of interest or financial conflicts to disclose.

This article is a review and does not contain any studies with human or animal subjects performed by any of the authors.

\section{References}

1. Maharajan T, Ceasar S A, Ajeesh krishna T P, Ramakrishnan M, Duraipandiyan V, Naif Abdulla A D, Ignacimuthu S, Ajeesh krishna T P, Ramakrishnan M, Duraipandiyan V, Naif Abdulla A D, Ignacimuthu S. Utilization of molecular markers for improving the phosphorus efficiency in crop plants. Plant Breeding, 2018, 137(1): 10-26

2. Pang J, Ryan M H, Lambers H, Siddique K H. Phosphorus acquisition and utilisation in crop legumes under global change. Current Opinion in Plant Biology, 2018, 45(Pt B): 248-254

3. Mapare S V, Yu P L, Sarkar A, Mukhopadhyay S C. A review of sensor technology for in-field phosphate monitoring. In: Seventh International Conference on Sensing Technology. Wellington, New Zealand: IEEE, 2013, 411-418

4. Ruttenberg K C. The global phosphorus cycle. Treatise on geochemistry, 2003, 8: 585-643

5. George T S, Giles C D, Menezes-Blackburn D, Condron L M, Gama-Rodrigues A C, Jaisi D, Lang F, Neal A L, Stutter M I, Almeida D S, Bol R, Cabugao K G, Celi L, Cotner J B, Feng G, Goll D S, Hallama M, Krueger J, Plassard C, Rosling A, Darch T, Fraser T, Giesler R, Richardson A E, Tamburini F, Shand C A, Lumsdon D G, Zhang H, Blackwell M S A, Wearing C, Mezeli M M, Almås R, Audette Y, Bertrand I, Beyhaut E, Boitt G, Bradshaw N, Brearley C A, Bruulsema T W, Ciais P, Cozzolino V, Duran P C, Mora M L, de Menezes A B, Dodd R J, Dunfield K, Engl C, Frazão J J, Garland G, González Jiménez J L, Graca J, Granger S J,
Harrison A F, Heuck C, Hou E Q, Johnes P J, Kaiser K, Kjær H A, Klumpp E, Lamb A L, Macintosh K A, Mackay E B, McGrath J, McIntyre C, McLaren T, Mészáros E, Missong A, Mooshammer M, Negrón C P, Nelson L A, Pfahler V, Poblete-Grant P, Randall M, Seguel A, Seth K, Smith A C, Smits M M, Sobarzo J A, Spohn M, Tawaraya K, Tibbett M, Voroney P, Wallander H, Wang L, Wasaki J, Haygarth P M. Organic phosphorus in the terrestrial environment: a perspective on the state of the art and future priorities. Plant and Soil, 2018, 427(1-2): 191-208

6. Negm A A, Abouzeid A Z M. Utilization of solid wastes from phosphate processing plants. Physicochemical Problems of Mineral Processing, 2008, 42: 5-16

7. Dodds W K, Whiles M R. Freshwater Ecology. 2 ed. Chapter 14: Nitrogen, sulfur, phosphorus, and other nutrients. 2012: 345-373. doi: 10.1016/B978-0-12-374724-2.00014-3

8. Gerke J. The acquisition of phosphate by higher plants: effect of carboxylate release by the roots. A critical review. Journal of Plant Nutrition and Soil Science, 2015, 178(3): 351-364

9. Wu P, Shou H, Xu G, Lian X. Improvement of phosphorus efficiency in rice on the basis of understanding phosphate signaling and homeostasis. Current Opinion in Plant Biology, 2013, 16(2): 205-212

10. Vance C P, Uhde-Stone C, Allan D L. Phosphorus acquisition and use: critical adaptations by plants for securing a nonrenewable resource. New Phytologist, 2003, 157(3): 423-447

11. Lassen R, Tjell J, Hansen J. Phosphorus recovery from sewage for agriculture. Waste Management \& Research, 1984, 2(4): 369-378

12. Shen J, Yuan L, Zhang J, Li H, Bai Z, Chen X, Zhang W, Zhang F. Phosphorus dynamics: from soil to plant. Plant Physiology, 2011, 156(3): 997-1005

13. Gamuyao R, Chin J H, Pariasca-Tanaka J, Pesaresi P, Catausan S, Dalid C, Slamet-Loedin I, Tecson-Mendoza E M, Wissuwa M, Heuer S. The protein kinase PSTOL1 from traditional rice confers tolerance of phosphorus deficiency. Nature, 2012, 488(7412): 535539

14. Weikard H P. Phosphorus recycling and food security in the long run: a conceptual modelling approach. Food Security, 2016, 8(2): 405-414

15. Zhang Y, Chen F J, Li X X, Li C J. Higher leaf area and post-silking $\mathrm{P}$ uptake conferred by introgressed DNA segments in the backcross maize line 224. Field Crops Research, 2013, 151: 78-84

16. Baker A, Ceasar S A, Palmer A J, Paterson J B, Qi W, Muench S P, Baldwin S A. Replace, reuse, recycle: improving the sustainable use of phosphorus by plants. Journal of Experimental Botany, 2015, 66(12): 3523-3540

17. Maharajan T, Ceasar S A, Ajeesh krishna T P, Ramakrishnan M, Duraipandiyan V, Naif Abdulla A D, Ignacimuthu S. Utilization of molecular markers for improving the phosphorus efficiency in crop plants. Plant Breeding, 2018, 137(1): 10-26

18. Liu Z, Gao K, Shan S, Gu R, Wang Z, Craft E J, Mi G, Yuan L, Chen F. Comparative analysis of root traits and the associated QTLs for maize seedlings grown in paper roll, hydroponics and vermiculite culture system. Frontiers of Plant Science, 2017, 8: 436

19. Khaldun A B M, Islam M T, Sheikh B, Rahman M. Integration of 
omics approaches for low-phosphorus tolerance in maize. In: Zargar S M, Vandna R, eds. Plant omics and crop breeding. Palm Bay, USA: Apple Academic Press, 2017, 260-287

20. Wang X R, Shen J B, Liao H. Acquisition or utilization, which is more critical for enhancing phosphorus efficiency in modern crops? Plant Science, 2010, 179(4): 302-306

21. Yuan Y, Gao M, Zhang M, Zheng H, Zhou X, Guo Y, Zhao Y, Kong F, Li S. QTL mapping for phosphorus efficiency and morphological traits at seedling and maturity stages in wheat. Frontiers of Plant Science, 2017, 8: 614

22. Mendes F F, Guimarães L J M, Souza J C, Guimarães P E O, Magalhaes J V, Garcia A A F, Parentoni S N, Guimaraes C T. Genetic architecture of phosphorus use efficiency in tropical maize cultivated in a low-P soil. Crop Science, 2014, 54(4): 1530-1538

23. Morais de Sousa S, Clark R T, Mendes F F, Carlos De Oliveira A, Vilaça De Vasconcelos M J, Parentoni S N, Kochian L V, Guimarães C T, Magalhães J V. A role for root morphology and related candidate genes in $\mathrm{P}$ acquisition efficiency in maize. Functional Plant Biology, 2012, 39(11): 925-935

24. López-Arredondo D L, Leyva-González M A, González-Morales S I, López-Bucio J, Herrera-Estrella L. Phosphate nutrition: improving low-phosphate tolerance in crops. Annual Review of Plant Biology, 2014, 65(1): 95-123

25. Wang W, Ding G D, White P J, Wang X H, Jin K M, Xu F S, Shi L. Mapping and cloning of quantitative trait loci for phosphorus efficiency in crops: opportunities and challenges. Plant and Soil, 2019, 439(1-2): 91-112

26. Gu R, Chen F, Long L, Cai H, Liu Z, Yang J, Wang L, Li H, Li J, Liu W, Mi G, Zhang F, Yuan L. Enhancing phosphorus uptake efficiency through QTL-based selection for root system architecture in maize. Journal of Genetics and Genomics, 2016, 43(11): 663-672

27. Parentoni S N, Souza Júnior C L. Phosphorus acquisition and internal utilization efficiency in tropical maize genotypes. Pesquisa Agropecuária Brasileira, 2008, 43(7): 893-901

28. Manske G G B, Ortiz-Monasterio J I, van Ginkel M, González R M, Fischer R A, Rajaram S, Vlek P L G. Importance of P uptake efficiency versus $\mathrm{P}$ utilization for wheat yield in acid and calcareous soils in Mexico. European Journal of Agronomy, 2001, 14(4): 261-274

29. Galindo-Castañeda T, Brown K M, Lynch J P. Reduced root cortical burden improves growth and grain yield under low phosphorus availability in maize. Plant, Cell \& Environment, 2018, 41(7): 1579-1592

30. Bayuelo-Jiménez J S, Gallardo-Valdéz M, Pérez-Decelis V A, Magdaleno-Armas L, Ochoa I, Lynch J P. Genotypic variation for root traits of maize (Zea mays L.) from the Purhepecha Plateau under contrasting phosphorus availability. Field Crops Research, 2011, 121(3): 350-362

31. Miguel M A, Widrig A, Vieira R F, Brown K M, Lynch J P. Basal root whorl number: a modulator of phosphorus acquisition in common bean (Phaseolus vulgaris). Annals of Botany, 2013, 112 (6): 973-982

32. Devaiah B N, Nagarajan V K, Raghothama K G. Phosphate homeostasis and root development in Arabidopsis are synchronized by the zinc finger transcription factor ZAT6. Plant
Physiology, 2007, 145(1): 147-159

33. Rouached H, Arpat A B, Poirier Y. Regulation of phosphate starvation responses in plants: signaling players and cross-talks. Molecular Plant, 2010, 3(2): 288-299

34. Baek D, Park H C, Kim M C, Yun D J. The role of Arabidopsis MYB2 in miR399f-mediated phosphate-starvation response. Plant Signaling \& Behavior, 2013, 8(3): e23488

35. Zhang K, Liu H, Song J, Wu W, Li K, Zhang J. Physiological and comparative proteome analyses reveal low-phosphate tolerance and enhanced photosynthesis in a maize mutant owing to reinforced inorganic phosphate recycling. BMC Plant Biology, 2016, 16(1): 129

36. Bera T, Mclamore E S, Wasik B, Rathinasabapathi B, Liu G. Identification of a maize (Zea mays L.) inbred line adapted to low-P conditions via analyses of phosphorus utilization, root acidification, and calcium influx. Journal of Plant Nutrition and Soil Science, 2018, 181(2): 275-286

37. Péret B, Desnos T, Jost R, Kanno S, Berkowitz O, Nussaume L. Root architecture responses: in search of phosphate. Plant Physiology, 2014, 166(4): 1713-1723

38. Bustos R, Castrillo G, Linhares F, Puga M I, Rubio V, Pérez-Pérez J, Solano R, Leyva A, Paz-Ares J. A central regulatory system largely controls transcriptional activation and repression responses to phosphate starvation in Arabidopsis. PLOS Genetics, 2010, 6 (9): e1001102

39. Cai H G, Chu Q, Gu R L, Yuan L X, Liu J C, Zhang X Z, Chen F J, Mi G H, Zhang F S. Identification of QTLs for plant height, ear height and grain yield in maize (Zea mays L.) in response to nitrogen and phosphorus supply. Plant Breeding, 2012, 131(4): 502-510

40. Xu C, Zhang H, Sun J, Guo Z, Zou C, Li W X, Xie C, Huang C, Xu $\mathrm{R}$, Liao $\mathrm{H}$, Wang $\mathrm{J}, \mathrm{Xu} \mathrm{X}$, Wang $\mathrm{S}, \mathrm{Xu} \mathrm{Y}$. Genome-wide association study dissects yield components associated with lowphosphorus stress tolerance in maize. Theoretical and Applied Genetics, 2018, 131(8): 1699-1714

41. Zhang H, Xu R, Xie C, Huang C, Liao H, Xu Y, Wang J, Li W X. Large-scale evaluation of maize germplasm for low-phosphorus tolerance. PLoS One, 2015, 10(5): e0124212

42. Pan L M, Yin Z Q, Huang Y Q, Chen J T, Zhu L Y, Zhao Y F, Guo J J. QTL for maize grain yield identified by QTL mapping in six environments and consensus loci for grain weight detected by meta-analysis. Plant Breeding, 2017, 136(6): 820-833

43. Raboanatahiry N, Chao H, Dalin H, Pu S, Yan W, Yu L, Wang B, Li M. QTL alignment for seed yield and yield related traits in Brassica napus. Frontiers of Plant Science, 2018, 9: 1127

44. Matsubara K, Yonemaru J I, Kobayashi N, Ishii T, Yamamoto E, Mizobuchi R, Tsunematsu H, Yamamoto T, Kato H, Yano M. A follow-up study for biomass yield QTLs in rice. PLoS One, 2018, 13(10): e0206054

45. Calderón-Vázquez C, Sawers R J H, Herrera-Estrella L. Phosphate deprivation in maize: genetics and genomics. Plant Physiology, 2011, 156(3): 1067-1077

46. Calderon-Vazquez C, Ibarra-Laclette E, Caballero-Perez J, Herrera-Estrella L. Transcript profiling of Zea mays roots reveals gene responses to phosphate deficiency at the plant- and species-specific levels. Journal of Experimental Botany, 2008, 59(9): 2479-2497 
47. Nagy R, Vasconcelos M J, Zhao S, McElver J, Bruce W, Amrhein N, Raghothama K G, Bucher M. Differential regulation of five Pht1 phosphate transporters from maize (Zea mays L.). Plant Biology, 2006, 8(2): 186-197

48. Pei L, Jin Z, Li K, Yin H, Wang J, Yang A. Identification and comparative analysis of low phosphate tolerance-associated microRNAs in two maize genotypes. Plant Physiology and Biochemistry, 2013, 70: 221-234

49. Du Q, Wang K, Zou C, Xu C, Li W X. The PILNCR1-miR399 regulatory module is important for low-phosphate tolerance in maize. Plant Physiology, 2018, 177(4): 1743-1753

50. Li K, Xu C, Li Z, Zhang K, Yang A, Zhang J. Comparative proteome analyses of phosphorus responses in maize (Zea mays L.) roots of wild-type and a low-P-tolerant mutant reveal root characteristics associated with phosphorus efficiency. Plant Journal, 2008, 55(6): 927-939

51. Li $\mathrm{K}, \mathrm{Xu} \mathrm{C}$, Fan $\mathrm{W}$, Zhang $\mathrm{H}$, Hou J, Yang A, Zhang $\mathrm{K}$. Phosphoproteome and proteome analyses reveal low-phosphate mediated plasticity of root developmental and metabolic regulation in maize (Zea mays L.). Plant Physiology and Biochemistry, 2014, 83: $232-242$

52. Ganie A H, Ahmad A, Pandey R, Aref I M, Yousuf P Y, Ahmad S, Iqbal M. Metabolite profiling of low-P tolerant and low-P sensitive maize genotypes under phosphorus starvation and restoration conditions. PLoS One, 2015, 10(6): e0129520

53. Buckler E S, Holland J B, Bradbury P J, Acharya C B, Brown P J, Browne C, Ersoz E, Flint-Garcia S, Garcia A, Glaubitz J C, Goodman M M, Harjes C, Guill K, Kroon D E, Larsson S, Lepak N K, Li H, Mitchell S E, Pressoir G, Peiffer J A, Rosas M O, Rocheford T R, Romay M C, Romero S, Salvo S, Sanchez Villeda H, da Silva H S, Sun Q, Tian F, Upadyayula N, Ware D, Yates H, Yu J, Zhang Z, Kresovich S, McMullen M D. The genetic architecture of maize flowering time. Science, 2009, 325(5941): 714-718

54. Reiter R S, Coors J G, Sussman M R, Gabelman W H. Genetic analysis of tolerance to low-phosphorus stress in maize using restriction fragment length polymorphisms. Theoretical and Applied Genetics, 1991, 82(5): 561-568

55. Kaeppler S M, Parke J L, Mueller S M, Senior L, Stuber C, Tracy W F. Variation among maize inbred lines and detection of quantitative trait loci for growth at low phosphorus and responsiveness to arbuscular mycorrhizal fungi. Crop Science, 2000, 40 (2): 358-364

56. Zhu J, Kaeppler S M, Lynch J P. Mapping of QTLs for lateral root branching and length in maize (Zea mays L.) under differential phosphorus supply. Theoretical and Applied Genetics, 2005, 111 (4): 688-695

57. Zhu J, Kaeppler S M, Lynch J P. Mapping of QTL controlling root hair length in maize (Zea mays L.) under phosphorus deficiency. Plant and Soil, 2005, 270(1): 299-310

58. Zhu J, Mickelson S M, Kaeppler S M, Lynch J P. Detection of quantitative trait loci for seminal root traits in maize (Zea mays $\mathrm{L}$.) seedlings grown under differential phosphorus levels. Theoretical and Applied Genetics, 2006, 113(1): 1-10

59. Chen J Y, Xu L, Cai Y L, Xu J. QTL mapping of phosphorus efficiency and relative biologic characteristics in maize (Zea mays
L.) at two sites. Plant and Soil, 2008, 313(1-2): 251-266

60. Chen J Y, Xu L, Cai Y L, Xu J. Identification of QTLs for phosphorus utilization efficiency in maize (Zea mays L.) across $\mathrm{P}$ levels. Euphytica, 2009, 167(2): 245-252

61. Li M, Guo X H, Zhang M, Wang X P, Zhang G D, Tian Y C, Wang $Z$ L. Mapping QTLs for grain yield and yield components under high and low phosphorus treatments in maize (Zea mays L.). Plant Science, 2010, 178(5): 454-462

62. Chen J Y, Cai Y L, Xu L, Wang J G, Zhang W L, Wang G Q, Xu D L, Chen T Q, Lu X G, Sun H Y, Huang A Y, Liang Y, Dai G L, Qin $\mathrm{H} \mathrm{N}$, Huang $\mathrm{Z} \mathrm{C}$, Zhu Z J, Yang Z G, Xu J, Kuang S F. Identification of QTLs for biomass production in maize (Zea mays L.) under different phosphorus levels at two sites. Frontiers of Agriculture in China, 2011, 5(2): 152-161

63. Chen J Y, Xu L. Comparative mapping of QTLs for $\mathrm{H}^{+}$secretion of root in maize (Zea mays L.) and cross phosphorus levels on two growth stages. Frontiers of Agriculture in China, 2011, 5(3): 284290

64. Chen J Y, Xu L. The candidate QTLs affecting phosphorus absorption efficiency and root weight in maize (Zea mays L.). Frontiers of Agriculture in China, 2011, 5(4): 456-462

65. Cai H G, Chu Q, Yuan L X, Liu J C, Chen X H, Chen F J, Mi G H, Zhang F S. Identification of quantitative trait loci for leaf area and chlorophyll content in maize (Zea mays) under low nitrogen and low phosphorus supply. Molecular Breeding, 2012, 30(1): 251266

66. Zhang G, Wang X, Wang B, Tian Y, Li M, Nie Y, Peng Q, Wang Z. Fine mapping a major QTL for kernel number per row under different phosphorus regimes in maize (Zea mays L.). Theoretical and Applied Genetics, 2013, 126(6): 1545-1553

67. Qiu H B, Mei X P, Liu C X, Wang J G, Wang G Q, Wang X, Liu Z, Cai Y L. Fine mapping of quantitative trait loci for acid phosphatase activity in maize leaf under low phosphorus stress. Molecular Breeding, 2013, 32(3): 629-639

68. Qiu H B, Liu C X, Yu T T, Mei X P, Wang G Q, Wang J G, Cai Y L. Identification of QTL for acid phosphatase activity in root and rhizosphere soil of maize under low phosphorus stress. Euphytica, 2014, 197(1): 133-143

69. Ni J J, Wu P, Senadhira D, Huang N. Mapping QTLs for phosphorus deficiency tolerance in rice (Oryza sativa L.). Theoretical and Applied Genetics, 1998, 97(8): 1361-1369

70. Wissuwa M, Wegner J, Ae N, Yano M. Substitution mapping of Pup1: a major QTL increasing phosphorus uptake of rice from a phosphorus-deficient soil. Theoretical and Applied Genetics, 2002, 105(6-7): 890-897

71. Xiao Y, Liu H, Wu L, Warburton M, Yan J. Genome-wide association studies in maize: praise and stargaze. Molecular Plant, 2017, 10(3): 359-374

72. Li H, Peng Z, Yang X, Wang W, Fu J, Wang J, Han Y, Chai Y, Guo T, Yang N, Liu J, Warburton M L, Cheng Y, Hao X, Zhang P, Zhao J, Liu Y, Wang G, Li J, Yan J. Genome-wide association study dissects the genetic architecture of oil biosynthesis in maize kernels. Nature Genetics, 2013, 45(1): 43-50

73. Wang X, Wang H, Liu S, Ferjani A, Li J, Yan J, Yang X, Qin F. Genetic variation in $Z m V P P 1$ contributes to drought tolerance in maize seedlings. Nature Genetics, 2016, 48(10): 1233-1241 
74. Yang N, Lu Y, Yang X, Huang J, Zhou Y, Ali F, Wen W, Liu J, Li J, Yan J. Genome wide association studies using a new nonparametric model reveal the genetic architecture of 17 agronomic traits in an enlarged maize association panel. PLOS Genetics, 2014, 10(9): e1004573

75. Luo B W, Ma P, Nie Z, Zhang X, He X, Ding X, Feng X, Lu Q X, Ren Z Y, Lin H J, Wu Y Q, Shen Y O, Zhang S Z, Wu L, Liu D, Pan G T, Rong T Z, Gao S B. Combining metabolite profiling with genome-wide association study to reveal response mechanisms of Zea mays seedlings under low-phosphorus conditions. Plant Journal, 2019, 97: 947-969

76. Yu J, Holland J B, McMullen M D, Buckler E S. Genetic design and statistical power of nested association mapping in maize. Genetics, 2008, 178(1): 539-551

77. Huang B E, Verbyla K L, Verbyla A P, Raghavan C, Singh V K, Gaur P, Leung H, Varshney R K, Cavanagh C R. MAGIC populations in crops: current status and future prospects. Theoretical and Applied Genetics, 2015, 128(6): 999-1017

78. Bandillo N, Raghavan C, Muyco P A, Sevilla M A, Lobina I T, Dilla-Ermita C J, Tung C W, McCouch S, Thomson M, Mauleon R, Singh R K, Gregorio G, Redoña E, Leung H. Multi-parent advanced generation inter-cross (MAGIC) populations in rice: progress and potential for genetics research and breeding. Rice, 2013, 6(1): 11

79. Holland J B. MAGIC maize: a new resource for plant genetics. Genome Biology, 2015, 16(1): 163

80. Dell'Acqua M, Gatti D M, Pea G, Cattonaro F, Coppens F, Magris G, Hlaing A L, Aung H H, Nelissen H, Baute J, Frascaroli E, Churchill G A, Inzé D, Morgante M, Pè M E. Genetic properties of the MAGIC maize population: a new platform for high definition QTL mapping in Zea mays. Genome Biology, 2015, 16(1): 167

81. Xiao Y, Tong H, Yang X, Xu S, Pan Q, Qiao F, Raihan M S, Luo Y, Liu H, Zhang X, Yang N, Wang X, Deng M, Jin M, Zhao L, Luo X, Zhou Y, Li X, Liu J, Zhan W, Liu N, Wang H, Chen G, Cai Y, Xu G, Wang W, Zheng D, Yan J. Genome-wide dissection of the maize ear genetic architecture using multiple populations. New Phytologist, 2016, 210(3): 1095-1106

82. Liu W X, Leiser W L, Reif J C, Tucker M R, Losert D, Weissmann S, Hahn V, Maurer H P, Würschum T. Multiple-line cross QTL mapping for grain yield and thousand kernel weight in triticale. Plant Breeding, 2016, 135(5): 567-573

83. Zhang L T, Li J, Rong T Z, Gao S B, Wu F K, Xu J, Li M L, Cao M J, Wang J, Hu E L, Liu Y X, Lu Y L. Large-scale screening maize germplasm for low-phosphorus tolerance using multiple selection criteria. Euphytica, 2014, 197(3): 435-446

84. Liu Z, Liu X, Craft E J, Yuan L, Cheng L, Mi G, Chen F. Physiological and genetic analysis for maize root characters and yield in response to low phosphorus stress. Breeding Science, 2018, 68(2): 268-277

85. Ige S A, Bello O B, Alake O. Combining ability and heterosis of tolerance to low soil nitrogen in tropical maize cultivars derived from two breeding eras. Open Agriculture, 2018, 3(1): 339-347

86. Narang R A, Altmann T. Phosphate acquisition heterosis in Arabidopsis thaliana: a morphological and physiological analysis. Plant and Soil, 2001, 234(1): 91-97

87. Nadeem M A, Nawaz M A, Shahid M Q, Doğan Y, Comertpay G,
Yıldız M, Hatipoğlu R, Ahmad F, Alsaleh A, Labhane N, Özkan H, Chung G, Baloch F S. DNA molecular markers in plant breeding: current status and recent advancements in genomic selection and genome editing. Biotechnology, Biotechnological Equipment, 2018, 32(2): 261-285

88. Devaiah B N, Madhuvanthi R, Karthikeyan A S, Raghothama K G. Phosphate starvation responses and gibberellic acid biosynthesis are regulated by the MYB62 transcription factor in Arabidopsis. Molecular Plant, 2009, 2(1): 43-58

89. Huang K L, Ma G J, Zhang M L, Xiong H, Wu H, Zhao C Z, Liu C S, Jia H X, Chen L, Kjorven J O, Li X B, Ren F. The ARF7 and ARF19 transcription factors positively regulate PHOSPHATE STARVATION RESPONSE1 in Arabidopsis roots. Plant Physiology, 2018, 178(1): 413-427

90. Chin J H, Gamuyao R, Dalid C, Bustamam M, Prasetiyono J, Moeljopawiro S, Wissuwa M, Heuer S. Developing rice with high yield under phosphorus deficiency: Pup1 sequence to application. Plant Physiology, 2011, 156(3): 1202-1216

91. Pérez-Torres C A, López-Bucio J, Cruz-Ramírez A, Ibarra-Laclette E, Dharmasiri S, Estelle M, Herrera-Estrella L. Phosphate availability alters lateral root development in Arabidopsis by modulating auxin sensitivity via a mechanism involving the TIRI auxin receptor. Plant Cell, 2008, 20(12): 3258-3272

92. Zhang H, Uddin M S, Zou C, Xie C, Xu Y, Li W X. Meta-analysis and candidate gene mining of low-phosphorus tolerance in maize. Journal of Integrative Plant Biology, 2014, 56(3): 262-270

93. Ran F A, Hsu P D, Wright J, Agarwala V, Scott D A, Zhang F. Genome engineering using the CRISPR-Cas9 system. Nature Protocols, 2013, 8(11): 2281-2308

94. Svitashev S, Schwartz C, Lenderts B, Young J K, Mark Cigan A. Genome editing in maize directed by CRISPR-Cas9 ribonucleoprotein complexes. Nature Communications, 2016, 7(1): 13274

95. Char S N, Neelakandan A K, Nahampun H, Frame B, Main M, Spalding M H, Becraft P W, Meyers B C, Walbot V, Wang K, Yang B. An Agrobacterium-delivered CRISPR/Cas9 system for highfrequency targeted mutagenesis in maize. Plant Biotechnology Journal, 2017, 15(2): 257-268

96. Meuwissen T H E, Hayes B J, Goddard M E. Prediction of total genetic value using genome-wide dense marker maps. Genetics, 2001, 157(4): 1819-1829

97. Hayes B J, Bowman P J, Chamberlain A C, Verbyla K, Goddard M E. Accuracy of genomic breeding values in multi-breed dairy cattle populations. Genetics, Selection, Evolution, 2009, 41(1): 51

98. Bernardo R, Yu J. Prospects for genomewide selection for quantitative traits in maize. Crop Science, 2007, 47(3): 1082-1090

99. Gaynor R C, Gorjanc G, Bentley A R, Ober E S, Howell P, Jackson R, Mackay I J, Hickey J M. A two-part strategy for using genomic selection to develop inbred lines. Crop Science, 2017, 57(5): 23722386

100. Riedelsheimer C, Endelman J B, Stange M, Sorrells M E, Jannink J L, Melchinger A E. Genomic predictability of interconnected biparental maize populations. Genetics, 2013, 194(2): 493-503

101. Schopp P, Müller D, Wientjes Y C J, Melchinger A E. Genomic prediction within and across biparental families: means and variances of prediction accuracy and usefulness of deterministic equations. G3: Genes, Genomes, Genetics, 2017, 7(11): 3571- 
3586

102. Zhang X, Pérez-Rodríguez P, Burgueño J, Olsen M, Buckler E, Atlin G, Prasanna B M, Vargas M, San Vicente F, Crossa J. Rapid cycling genomic selection in a multiparental tropical maize population. G3: Genes, Genomes, Genetics, 2017, 7(7): 23152326

103. Lorenzana R E, Bernardo R. Accuracy of genotypic value predictions for marker-based selection in biparental plant populations. Theoretical and Applied Genetics, 2009, 120(1): 151-161

104. Windhausen V S, Atlin G N, Hickey J M, Crossa J, Jannink J L, Sorrells M E, Raman B, Cairns J E, Tarekegne A, Semagn K, Beyene Y, Grudloyma P, Technow F, Riedelsheimer C, Melchinger A E. Effectiveness of genomic prediction of maize hybrid performance in different breeding populations and environments. Genetics, 2012, 2(11): 1427-1436

105. Albrecht T, Auinger H J, Wimmer V, Ogutu J O, Knaak C, Ouzunova M, Piepho H P, Schön C C. Genome-based prediction of maize hybrid performance across genetic groups, testers, locations, and years. Theoretical and Applied Genetics, 2014, 127(6): 13751386

106. Massman J M, Gordillo A, Lorenzana R E, Bernardo R. Genomewide predictions from maize single-cross data. Theoretical and Applied Genetics, 2013, 126(1): 13-22

107. Zhong S, Dekkers J C M, Fernando R L, Jannink J L. Factors affecting accuracy from genomic selection in populations derived from multiple inbred lines: a barley case study. Genetics, 2009, 182 (1): 355-364

108. Daetwyler H D, Pong-Wong R, Villanueva B, Woolliams J A. The impact of genetic architecture on genome-wide evaluation methods. Genetics, 2010, 185(3): 1021-1031

109. Clark S A, Hickey J M, Daetwyler H D, van der Werf J H. The importance of information on relatives for the prediction of genomic breeding values and the implications for the makeup of reference data sets in livestock breeding schemes. Genetics, Selection, Evolution, 2012, 44(1): 4

110. Wang Q, Yu Y, Yuan J, Zhang X, Huang H, Li F, Xiang J. Effects of marker density and population structure on the genomic prediction accuracy for growth trait in Pacific white shrimp Litopenaeus vannamei. BMC Genetics, 2017, 18(1): 45

111. Lyra D H, de Freitas Mendonça L, Galli G, Alves F C, Granato Í S C, Fritsche-Neto R. Multi-trait genomic prediction for nitrogen response indices in tropical maize hybrids. Molecular Breeding, 2017, 37(6): 80

112. Gorjanc G, Jenko J, Hearne S J, Hickey J M. Initiating maize prebreeding programs using genomic selection to harness polygenic variation from landrace populations. BMC Genomics, 2016, 17(1): 30

113. Nass L L, Paterniani E. Pre-breeding: a link between genetic resources and maize breeding. Scientia Agrícola, 2007, 57(3): 581-587

114. Sachs M M. Cereal germplasm resources. Plant Physiology, 2009, 149(1): 148-151

115. Schnable P S, Ware D, Fulton R S, Stein J C, Wei F, Pasternak S, Liang C, Zhang J, Fulton L, Graves T A, Minx P, Reily A D, Courtney L, Kruchowski S S, Tomlinson C, Strong C, Delehaunty K, Fronick C, Courtney B, Rock S M, Belter E, Du F, Kim K,
Abbott R M, Cotton M, Levy A, Marchetto P, Ochoa K, Jackson S M, Gillam B, Chen W, Yan L, Higginbotham J, Cardenas M, Waligorski J, Applebaum E, Phelps L, Falcone J, Kanchi K, Thane T, Scimone A, Thane N, Henke J, Wang T, Ruppert J, Shah N, Rotter K, Hodges J, Ingenthron E, Cordes M, Kohlberg S, Sgro J, Delgado B, Mead K, Chinwalla A, Leonard S, Crouse K, Collura K, Kudrna D, Currie J, He R, Angelova A, Rajasekar S, Mueller T, Lomeli R, Scara G, Ko A, Delaney K, Wissotski M, Lopez G, Campos D, Braidotti M, Ashley E, Golser W, Kim H, Lee S, Lin J, Dujmic Z, Kim W, Talag J, Zuccolo A, Fan C, Sebastian A, Kramer M, Spiegel L, Nascimento L, Zutavern T, Miller B, Ambroise C, Muller S, Spooner W, Narechania A, Ren L, Wei S, Kumari S, Faga B, Levy M J, McMahan L, Van Buren P, Vaughn M W, Ying K, Yeh C T, Emrich S J, Jia Y, Kalyanaraman A, Hsia A P, Barbazuk W B, Baucom R S, Brutnell T P, Carpita N C, Chaparro C, Chia J M, Deragon J M, Estill J C, Fu Y, Jeddeloh J A, Han Y, Lee H, Li P, Lisch D R, Liu S, Liu Z, Nagel D H, McCann M C, SanMiguel P, Myers A M, Nettleton D, Nguyen J, Penning B W, Ponnala L, Schneider K L, Schwartz D C, Sharma A, Soderlund C, Springer N M, Sun Q, Wang H, Waterman M, Westerman R, Wolfgruber T K, Yang L, Yu Y, Zhang L, Zhou S, Zhu Q, Bennetzen J L, Dawe R K, Jiang J, Jiang N, Presting G G, Wessler S R, Aluru S, Martienssen R A, Clifton S W, McCombie W R, Wing R A, Wilson R K. The B73 maize genome: complexity, diversity, and dynamics. Science, 2009, 326(5956): 1112-1115

116. Liu H, Luo X, Niu L, Xiao Y, Chen L, Liu J, Wang X, Jin M, Li W, Zhang Q, Yan J. Distant eQTLs and non-coding sequences play critical roles in regulating gene expression and quantitative trait variation in maize. Molecular Plant, 2017, 10(3): 414-426

117. Bukowski R, Guo X, Lu Y, Zou C, He B, Rong Z, Wang B, Xu D, Yang B, Xie C, Fan L, Gao S, Xu X, Zhang G, Li Y, Jiao Y, Doebley J F, Ross-Ibarra J, Lorant A, Buffalo V, Romay M C, Buckler E S, Ware D, Lai J, Sun Q, Xu Y. Construction of the thirdgeneration Zea mays haplotype map. GigaScience, 2018, 7(4): 112

118. Yang W, Duan L, Chen G, Xiong L, Liu Q. Plant phenomics and high-throughput phenotyping: accelerating rice functional genomics using multidisciplinary technologies. Current Opinion in Plant Biology, 2013, 16(2): 180-187

119. Yang W, Guo Z, Huang C, Duan L, Chen G, Jiang N, Fang W, Feng H, Xie W, Lian X, Wang G, Luo Q, Zhang Q, Liu Q, Xiong L. Combining high-throughput phenotyping and genome-wide association studies to reveal natural genetic variation in rice. Nature Communications, 2014, 5(1): 5087

120. Abe A, Kosugi S, Yoshida K, Natsume S, Takagi H, Kanzaki H, Matsumura H, Yoshida K, Mitsuoka C, Tamiru M, Innan H, Cano L, Kamoun S, Terauchi R. Genome sequencing reveals agronomically important loci in rice using MutMap. Nature Biotechnology, 2012, 30(2): 174-178

121. Liu S, Yeh C T, Tang H M, Nettleton D, Schnable P S. Gene mapping via bulked segregant RNA-Seq (BSR-Seq). PLoS One, 2012, 7(5): e36406

122. Takagi H, Abe A, Yoshida K, Kosugi S, Natsume S, Mitsuoka C, Uemura A, Utsushi H, Tamiru M, Takuno S, Innan H, Cano L M, Kamoun S, Terauchi R. QTL-seq: rapid mapping of quantitative trait loci in rice by whole genome resequencing of DNA from two 
bulked populations. Plant Journal, 2013, 74(1): 174-183

123. Zhang H, Wang X, Pan Q, Li P, Liu Y, Lu X, Zhong W, Li M, Han L, Li J, Wang P, Li D, Liu Y, Li Q, Yang F, Zhang Y M, Wang G, Li L. QTG-Seq accelerates QTL fine mapping through QTL partitioning and whole-genome sequencing of bulked segregant samples. Molecular Plant, 2019, 12(3): 426-437

124. Yang J, Jiang H, Yeh C T, Yu J, Jeddeloh J A, Nettleton D, Schnable P S. Extreme-phenotype genome-wide association study (XP-GWAS): a method for identifying trait-associated variants by sequencing pools of individuals selected from a diversity panel. Plant Journal, 2015, 84(3): 587-596

125. Zou C, Wang P, Xu Y. Bulked sample analysis in genetics, genomics and crop improvement. Plant Biotechnology Journal, 2016, 14(10): 1941-1955

126. Wang W, Mauleon R, Hu Z, Chebotarov D, Tai S, Wu Z, Li M, Zheng T, Fuentes R R, Zhang F, Mansueto L, Copetti D, Sanciangco M, Palis K C, Xu J, Sun C, Fu B, Zhang H, Gao Y, Zhao X, Shen F, Cui X, Yu H, Li Z, Chen M, Detras J, Zhou Y, Zhang X, Zhao Y, Kudrna D, Wang C, Li R, Jia B, Lu J, He X, Dong Z, Xu J, Li Y, Wang M, Shi J, Li J, Zhang D, Lee S, Hu W, Poliakov A, Dubchak I, Ulat V J, Borja F N, Mendoza J R, Ali J, Li J, Gao Q, Niu Y, Yue Z, Naredo M E B, Talag J, Wang X, Li J, Fang X, Yin Y, Glaszmann J C, Zhang J, Li J, Hamilton R S, Wing R A, Ruan J, Zhang G, Wei C, Alexandrov N, McNally K L, Li Z, Leung H. Genomic variation in 3,010 diverse accessions of Asian cultivated rice. Nature, 2018, 557(7703): 43-49

127. Xu X, Liu X, Ge S, Jensen J D, Hu F, Li X, Dong Y, Gutenkunst R N, Fang L, Huang L, Li J, He W, Zhang G, Zheng X, Zhang F, Li Y, Yu C, Kristiansen K, Zhang X, Wang J, Wright M, McCouch S, Nielsen R, Wang J, Wang W. Resequencing 50 accessions of cultivated and wild rice yields markers for identifying agronomically important genes. Nature Biotechnology, 2012, 30(1): 105111

128. Yang X H, Gao S B, Xu S T, Zhang Z X, Prasanna B M, Li L, Li J $\mathrm{S}$, Yan J B. Characterization of a global germplasm collection and its potential utilization for analysis of complex quantitative traits in maize. Molecular Breeding, 2011, 28(4): 511-526

129. Yang M, Wang X, Ren D, Huang H, Xu M, He G, Deng X W. Genomic architecture of biomass heterosis in Arabidopsis. Proceedings of the National Academy of Sciences of the United
States of America, 2017, 114(30): 8101-8106

130. Huang X, Yang S, Gong J, Zhao Y, Feng Q, Gong H, Li W, Zhan Q, Cheng B, Xia J, Chen N, Hao Z, Liu K, Zhu C, Huang T, Zhao Q, Zhang L, Fan D, Zhou C, Lu Y, Weng Q, Wang Z X, Li J, Han B. Genomic analysis of hybrid rice varieties reveals numerous superior alleles that contribute to heterosis. Nature Communications, 2015, 6(1): 6258

131. Asoro F G, Newell M A, Beavis W D, Scott M P, Jannink J L. Accuracy and training population design for genomic selection on quantitative traits in elite North American oats. Plant Genome, 2011, 4(2): 132-144

132. Wientjes Y C J, Veerkamp R F, Calus M P L. The effect of linkage disequilibrium and family relationships on the reliability of genomic prediction. Genetics, 2013, 193(2): 621-631

133. Crossa J, Pérez P, Hickey J, Burgueño J, Ornella L, Cerón-Rojas J, Zhang X, Dreisigacker S, Babu R, Li Y, Bonnett D, Mathews K. Genomic prediction in CIMMYT maize and wheat breeding programs. Heredity, 2014, 112(1): 48-60

134. Bernardo R. Genomewide selection when major genes are known. Crop Science, 2014, 54(1): 68-75

135. Jacobson A, Lian L, Zhong S, Bernardo R. General combining ability model for genome-wide selection in a biparental cross. Crop Science, 2014, 54(3): 895-905

136. Covarrubias-Pazaran G. Genome-assisted prediction of quantitative traits using the R package sommer. PLoS One, 2016, 11(6): e0156744

137. Cuevas J, Crossa J, Soberanis V, Pérez-Elizalde S, PérezRodríguez P, Campos G L, Montesinos-López O A, Burgueño J. Genomic prediction of genotype $\times$ environment interaction kernel regression models. Plant Genome, 2016, 9(3): 1-20

138. Crossa J, Campos G D L, Maccaferri M, Tuberosa R, Burgueño J, Pérez-rodríguez $\mathrm{P}$. Extending the marker $\times$ environment interaction model for genomic-enabled prediction and genome-wide association analysis in durum wheat. Crop Science, 2016, 56(5): 2193-2209

139. Jarquín D, Crossa J, Lacaze X, Du Cheyron P, Daucourt J, Lorgeou J, Piraux F, Guerreiro L, Pérez P, Calus M, Burgueño J, de los Campos G. A reaction norm model for genomic selection using high-dimensional genomic and environmental data. Theoretical and Applied Genetics, 2014, 127(3): 595-607 